\title{
ACCUMULATION AND HISTOLOGICAL OBSERVATION OF HEAVY METAL IN Brassica campestris L. AND Chenopodium album L. GROWING ON SLUDGE OF PULP PAPER INDUSTRY AFTER SECONDARY TREATMENT
}

\section{Pooja Sharma, Sonam Tripathi, Ram Chandra*}

Department of Environmental Microbiology, School for Environmental Sciences, Babasaheb Bhimrao Ambedkar Central University, Vidya Vihar, Rae Bareli Road, Lucknow, Uttar Pradesh-226025, India

Received - May 01, 2020; Revision - May 25, 2020; Accepted - June 01, 2020

Available Online - June 25, 2020

DOI: http://dx.doi.org/10.18006/2020.8(3).320.333

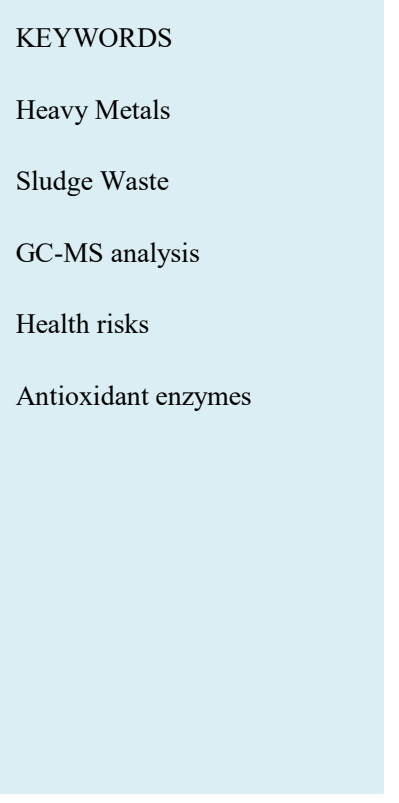

\begin{abstract}
The discharged sludge from the pulp paper industry contains several organic and inorganic pollutants even after secondary treatment, which might cause toxicity in plants. The present study was designed to investigate the accumulation and histological findings of heavy metal in Brassica campestris and Chenopodium album growing on sludge waste of pulp paper industry after secondary treatment. The physico-chemical analysis of sludge viz., $\mathrm{pH}$, total solid $\left(2678 \mathrm{mg} \mathrm{L}^{-1}\right)$, total dissolved solid $\left(2756 \mathrm{mg} \mathrm{L}^{-1}\right)$, total suspended solid (189 mg L $\mathrm{m}^{-1}$ ), chemical oxygen demand (43587 $\mathrm{mg} \mathrm{L}^{-1}$ ), biological oxygen demand (1569 $\left.\mathrm{mg} \mathrm{L}^{-1}\right)$, and electric conductivity $\left(2067 \mathrm{~ms} \mathrm{~cm}^{-1}\right)$ contents in it were found beyond the permissible limit. The result of study revealed that the heavy metal content in sludge viz., $\mathrm{Cu}$ (59), $\mathrm{Ni}$ (66), $\mathrm{Fe}(153)$, $\mathrm{Mn}$ (9.37) $\mathrm{Zn}$ (12.31) and $\mathrm{Mg}$ (11.8 $\left.\mathrm{mg} \mathrm{L}^{-1}\right)$. Furthermore, the chlorophyll and carotenoids contents in $B$. campestris and C. album was (Chl-a 4.57-5.21 mg g ${ }^{-1} \mathrm{fw}$ ), (chl-b 5.29-5.89 $\mathrm{mg} \mathrm{g}^{-1} \mathrm{fw}$ ), and (carotenoids 0.84-1.07 $\mathrm{mg} \mathrm{g}^{-1} \mathrm{fw}$ ) also high. The effect of heavy metals on antioxidants enzyme of $B$. campestris and $C$. album growing on organometallic containing sludge waste was observed to be high. Further, the concentrations of heavy metals in B. campestris and C. album were reported in descending order as $\mathrm{Fe}$ $(211-208)>\mathrm{Cu}(62.37-49.87)>\mathrm{Zn}(56.67-34.26)>\mathrm{Mn}(36.37-42.37)>\mathrm{Mg}(35.69-13.64)>\mathrm{Ni}(9.36-6.51$ $\left.\mathrm{mg} \mathrm{kg}^{-1}\right)$ root $>$ shoot $>$ leaves respectively. Hence the result of study concluded that pulp paper industry sludge is the main source of metals accumulation in crop plants, and need to be appropriately treated before discharge in the environment for human and animal health safety.
\end{abstract}

* Corresponding author

E-mail: prof.chandrabbau@gmail.com; rc_microitrc@yahoo.co.in (R. Chandra)

Peer review under responsibility of Journal of Experimental Biology and Agricultural Sciences.

Production and Hosting by Horizon Publisher India [HPI] (http://www.horizonpublisherindia.in/).

All rights reserved.
All the articles published by Journal of Experimental Biology and Agricultural Sciences are licensed under a Creative Commons Attribution-NonCommercial 4.0 International License Based on a work at www.jebas.org.

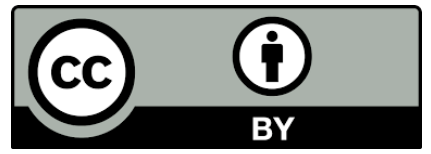




\section{Introduction}

Environmental pollution and contamination by heavy metals is a threat to the environment and is of serious concern to plants. Rapid industrialization and urbanization have caused pollution of the environment owing to heavy metals, and their rate of mobilization, transport and accumulation in the environment has accelerated significantly since the 1940 (Khan et al., 2004). The main sources of heavy metals in the environment include metallurgical work, urbanization, and industrialization, particularly in highly populated developing countries such as China and India (Un-Habitat, 2004). Moreover, in the year 2017, approximately 411 million tons of worldwide paper production accounted mostly in countries such as India, China, Brazil, European country and USA (Bayı Demirel \& Altın, 2017). The pulp paper industry might be releasing 55-60\% sludge wastes containing nitrogen, potassium, calcium, phosphorus, iron, magnesium, copper, silicon, zinc and manganese compounds, although during pulping process only $40-45 \%$ of the pulp is obtained (Ali \& Sreekrishnan, 2001). Consequently, approximately $190-200 \mathrm{~m}^{3}$ of freshwater is utilized per ton of paper production and sludge is about $0.04-0.5 \mathrm{~m}^{3}$ dry weight of sludge in North American paper mills (Chandra \& Singh, 2012; Bajpai, 2015). Furthermore, the environmental protection agency (EPA) in United States reports more than 250 million tonnes of municipal solid waste to be generated every year, of which approximately $30 \%$ are related to pulp paper industry waste, while one ton of paper produced generate approximately 0.4 tons of waste discharged in the environment without proper treatment (IPPC, 2001; EPA, 2002). In addition, the sludge waste generated during the paper manufacturing from the paper industry is divided into four categories as follows: first is the primary sludge wastes generated by the production of virgin wood fibers; second is the destination sludge wastes generated by removal of the fiber ink; third include activated waste after biological treatment that is secondary sludge; fourth is the waste from paper production for biological purposes which is complex sludge. In the biological process, microorganisms transform the organic matter of the sludge waste into a type of soil fertilizer (Boni et al., 2004). The discharged sludge waste contains chlorinated compounds measured as adsorbable organic halides (AOX) that can bio-accumulate in fish tissue causing a range of clastogenic, endocrine and mutagenic impacts (Savant, et al., 2006).

India is a developing country where farmers do not have sufficient resources for irrigation of agricultural crops; therefore, they use industrial wastewater as a source of water with a higher level of toxic heavy metals. Moreover, several heavy metals have adverse effects on different enzymes including acid phosphatases, proteases, and $\alpha$-amylases and protein profiles involved in germination of seeds. For instance, heavy metals have been reported to decrease the starch content, reduce the nutrient content, impair the PS-II of the chloroplast, and induce the expression of heat shock proteins and proline (Seneviratne et al., 2019). Similar observation of heavy metal accumulation and effect of production, biomass and physiological processes in mustard was also reported by Sheetal et al., (2016).

Wild plants are important components of ecosystem as their distribution help in keeping the environment clean. Chenopodium album constitutes common weeds of cultivated fields and widely distributed in many parts of the world. Information on metal accumulation in Chenopodiaceae species has been widely reported among weeds with these characteristics (Tozser et al., 2019). Similarly, Brassica species are very common agricultural crops in various parts of the world and are also considered to be heavy metal ( $\mathrm{Fe}, \mathrm{Cu}, \mathrm{Zn}, \mathrm{Ni}, \mathrm{Pb}, \mathrm{Mn}, \mathrm{Cd}$ and $\mathrm{Mg}$ ) accumulators (Mourato et al., 2015). This study aimed to analyze accumulation and histological findings of heavy metal in B. campestris and C. album growing commonly on sludge waste of pulp paper industry after even secondary treatment at industrial level. In the present study, the effect of heavy metals on antioxidants enzyme of $B$. campestris and $C$. album growing on organometallic containing sludge waste was found to be high. Furthermore, this manuscript discusses the toxicity of pulp paper industry sludge and metals as accumulated by plants that causes health risks for humans and animal via foodchain consumption. Brassica species are significant in the production of oil, both for human food and for the production of biodiesel; the potential contamination of seeds and oil from these plants was also the objective of some studies, as this could lead to pollution of the food chain and the environment. The study included accumulation, uptake, effect, and distribution of heavy metals in selected plants from the disposal site of the pulp paper industry waste. Consequently, the biochemical changes in plants by the stress of metals and their phytoextraction efficiency could be deleterious.

\section{Material and Methods}

\subsection{Collection of sludge and plant samples}

The fresh effluent samples were collected from the M/s KR Pulp Paper Industry, Shahjahanpur, Uttar Pradesh, India (27050'31.8"N $\left.79^{\circ} 51^{\prime} 15.7^{\prime \prime E}\right)$. For this study, sludge samples were collected in a 20 kg (Tarson Production Pvt. Ltd., USA) sterile plastic bag from disposal site. The effluent samples were collected using a sterile plastic container and stored at $4{ }^{\circ} \mathrm{C}$ until further use. Furthermore, two characteristic plant species i.e. $B$ campestris (Brassicaceae) and $C$. album (Amaranthaceae) were identified and collected on the basis of abundantly growing on sludge. In addition, the study of normal plant (as control) growth plant sample was collected from normal agriculture land. This process was repeated three times in different seasons from the same place for the confirmation and authenticity of scientific data. 


\subsection{Physico-chemical analysis of sludge}

The sludge samples were analyzed within 48 hours for total dissolved solid (TDS), total solid (TS), total suspended solid (TSS), biochemical oxygen demand (BOD), electric conductivity (EC), chemical oxygen demand (COD), total nitrogen (micro kjeldahl), sulphates, total phenols, lignin, chlorophenols, phosphate and color (visual color comparison method) as per standard methods (American Public Health Association, 2012). The pH, chloride, sodium and potassium concentrations were also analyzed using the Thermo Orion (Model 960) selective ion electrode. While, the heavy metals $(\mathrm{Cu}, \mathrm{Ni}, \mathrm{Fe}, \mathrm{Mn}, \mathrm{Zn}$ and $\mathrm{Mg})$ in effluent were analyzed by the atomic absorption spectrophotometer (AAS; ZEEnit 700, Analytic Jena, Germany).

\subsection{Scanning Electron Microscopy and UV-Vis Spectroscopy Analysis}

The surface structure investigation of the sludge samples was done by scanning electron microscopy (SEM) analysis. The sample was completely dried in the hot air oven (Thermo Scientific) at $50^{\circ} \mathrm{C}$, the dried sample was converted into $10 \mathrm{mg}$ powder form as described by Yadav \& Chandra (2018). Moreover, the sample was fixed with $2.5 \%$ glutaraldehyde at $4{ }^{\circ} \mathrm{C}$ for $2-4 \mathrm{~h}$ and washed with $0.1 \mathrm{M}$ thrice phosphate buffer for 3 times each of $15 \mathrm{~min}$, for the post-fixation in $1 \%$ osmium tetroxide for $2 \mathrm{~h}$. Subsequently, samples were dehydrated with acetone at different concentration $(15 \%, 30 \%, 50 \%, 70 \%, 90 \%$, $95 \%$ and $100 \%$ ) for $30 \mathrm{~min}$ each. Every step was performed at $4^{\circ} \mathrm{C}$. Samples were finally mounted on aluminum stubbing with double-sided carbon tape, sputter-coated with platinum coater (Auto Fine Coater JFC- 1600 JEOL, Japan). The samples were analyzed by JEOL JSM 6490 LV (Tokyo, Japan) scanning electron microscope at different magnifications and accelerating $15 \mathrm{kV}$ voltages. In addition, the UV-Vis spectrometry analysis of sludge sample $(1: 10)$ was performed to observe the absorbance parameter of different complex organic pollutants at different height of peak in a range of 200-700 nm using a Thermo Fisher Scientific Shanghai spectrophotometer (Evolution 201, China) (Yadav \& Chandra, 2018).

\subsection{Detection of pollutants from sludge}

\subsubsection{Solid-liquid extraction}

The detection of a broad range of different organic compounds and other endocrine-disrupting chemicals (EDCs) present in the discharged sludge were extracted using dichloromethane (DCM) solvent (Chandra \& Abhishek, 2011). A $10 \mathrm{~g}$ of fresh sludge sample was weighed and $25 \mathrm{ml}$ of DCM added to separating funnel $(500 \mathrm{ml})$, and shaked vigorously the nozzle of separating funnel, that was released finally, for drop out of extracted solution. This process was repeated thricely in order to collect the layer of organic compounds. The dry residue obtained was dissolved in 2.0 $\mathrm{ml}$ DCM and filtered through $0.22 \mu \mathrm{M}$ syringe filters (Millipore Ltd., Bedford, Massachusetts, USA), it was finally makeup to 3.0 $\mathrm{ml}$ for GC-MS analysis.

\subsubsection{Characterization of organic pollutants through GC-MS}

For the identification of organic pollutants present in sludge, after the extraction samples, $200 \mu \mathrm{l}$ was transferred into GC vials and dried with nitrogen gas. Adding $50 \mu 1$ of pyridine to the dry sample and then subjecting it to silylation with $80 \mu$ trimethylsilyl BSTFA and TMCS was followed. In addition, the mixture of the sample was heated at $70^{\circ} \mathrm{C}$ for 30 min with periodic shaking, after which it was subjected to GC-MS analysis. The organic pollutants were identified by comparing their mass spectra $(\mathrm{m} / \mathrm{z})$ with recorded different retention time (RT) in the NIST library (Chandra \& Abhishek, 2011)

\subsection{Estimation of biochemical parameters}

\subsubsection{Protein content and photosynthetic pigments}

The measurement of protein content in plants grown on a treated sludge and agriculture land (control) was assessed by using bovine serum albumin (Sigma) as per the described standard method (Lowry et al., 1951). In addition, the estimation of photosynthetic pigments such as Chl- a and Chl-b, the fresh leaves sample of 100 mg were crushed in $5 \mathrm{ml}$ of chilled $80 \%$ acetone with the help of pestle and mortar (Arnon, 1949). The sample was then centrifuged at 5,000 rpm for $10 \mathrm{~min}$ at $4^{\circ} \mathrm{C}$ and the supernatant was collected and the chlorophyll content was measured in a spectrophotometer (UV-160, Shimadzu, Japan). The carotenoids content was also estimated as per the same above process and reading analysis of the supernatants at a wavelength of 480 and $510 \mathrm{~nm}$ (Duxbury \& Yentsch, 1956).

\subsubsection{Preparation of enzyme extract}

For the preparation of enzyme extract for estimation of antioxidants analysis, $250 \mathrm{mg}$ fresh leaves were added to $3 \mathrm{ml}$ of $100 \mu \mathrm{M}$ potassium phosphate buffer ( $\mathrm{pH}$ 7.5) containing $1 \mathrm{mM}$ of ETDA and polyvinylpolypyrrolidone (PVP), and crushed with mortar and pestle. The sample was centrifuged at $12,000 \mathrm{rpm}$ for 10 min at $4{ }^{\circ} \mathrm{C}$ and the supernatant was separated to measure the activity of different antioxidant enzymes.

\subsubsection{Catalase assay and hydrogen peroxidase}

The estimation of catalase (CAT) enzyme activity in treated plant as compared to control was measured by adding in a reaction mixture prepared with $50 \mathrm{mM} / \mathrm{L}$ phosphate buffer ( $\mathrm{pH} 7.0), 150$ $\mathrm{mM} / \mathrm{L} \mathrm{H}_{2} \mathrm{O}_{2}$ for $2 \mathrm{~min}$ and OD was recorded at $240 \mathrm{~nm}$ (Nishikimi 
et al., 1972). In addition, the peroxidase (POD) activity was determined by using the 4-methyl catechol substrate. While, the increase in absorbance caused by oxidation of 4-methyl catechol by $\mathrm{H}_{2} \mathrm{O}_{2}$ was measured at $420 \mathrm{~nm}$ spectrophotometrically (UV160, Shimadzu, Japan). The mixture of a reaction containing with $5 \mathrm{mM}$ 4-methylcatechol, $100 \mathrm{mM}$ sodium phosphate buffer $(\mathrm{pH}$ 7.0), $500 \mu \mathrm{L}$ of crude extract was made in a total volume of $3.0 \mathrm{~mL}$ at room temperature (Onsa et al., 2004). In addition, the estimation of $\mathrm{H}_{2} \mathrm{O}_{2}$ was recorded in the same process performed and absorbance was recorded at $350 \mathrm{~nm}$ as per the described method of Velikova et al. (2000).

\subsubsection{Ascorbate, superoxide dismutase and ascorbate peroxidase assay}

For the estimation of ascorbate from treated plant and control, the $50 \mathrm{mg}$ of fresh plants leaves sample was homogenized with $2 \mathrm{ml}$ of enzyme extract. The sample was centrifuged at 2,500 rpm for 15 $\min$ at $4^{\circ} \mathrm{C}$. The supernatant collected was used to measure ascorbate at $520 \mathrm{~nm}$ within $2 \pm 5 \mathrm{~min}$ as per the method of Keller \& Schwager (1977). The activity of superoxide dismutase assay (SOD) was measured by observing the inhibition in photoreduction of nitroblue tetrazolium (NBT) by SOD enzyme (Nishikimi et al., 1972). The amount of enzyme required to inhibit the $50 \%$ reduction of NBT is expressed as one unit of the enzyme. Further, the absorbance was recorded at $560 \mathrm{~nm}$ using a spectrophotometer. The estimation of ascorbate peroxidase (APX) enzyme was measured by recording the oxidation of ascorbate in presence of $\mathrm{H}_{2} \mathrm{O}_{2}$ at $250 \mathrm{~nm}$ in terms of decreases in absorbance and the activity of APX as expressed in terms of $\mathrm{mM}$ ascorbate oxidized $\mathrm{min}^{-1} \mathrm{~g}^{-1}$ of weight (Nakano \& Asada, 1981).

\subsection{Estimation of heavy metal in plants}

To estimate the concentration of different heavy metals in the different parts of the B. campestris and C. album plants growing at the sludge bed, the collected plants were subsequently segregated into roots, shoot and leaves and the samples were incubated at $70^{\circ} \mathrm{C}$ for 7 days. Consequently, the dried samples were then ashed in a muffle furnace at $460^{\circ} \mathrm{C}$ for $6 \mathrm{~h}$ and digested with $2 \% \mathrm{HNO}_{3}$, and digestion continued until brown fumes were gone method by 3050-B. The samples were then filtered through a $0.45 \mu \mathrm{M}$ glass fiber filter (EPA, 1996; AOAC, 2002). The concentrations of heavy metals $(\mathrm{Cu}, \mathrm{Ni}, \mathrm{Fe}, \mathrm{Mn}, \mathrm{Zn}$, and $\mathrm{Mg})$ in different parts of plant i.e. root, shoot and leaves was measured by AAS.

\subsection{Histological observations of root tissues by Transmission Electron Microscopy}

For the histological observation of heavy metal accumulation inside the B. campestris and C. album root tissue, the root tips were cut approximately to $2.0 \mathrm{~mm}$ for section cutting and fixed with $2.5 \%$ glutaraldehyde solution. For the precipitation of trace elements from the root, samples were added to $\mathrm{H}_{2} \mathrm{~S}$ saturated water for 30 minutes at $37^{\circ} \mathrm{C}$ (Khan et al., 1984). The root was washed again with $0.1 \mathrm{M}$ sodium cacodylate buffer ( $\mathrm{SCB}$ ), at $\mathrm{pH}$ (7.2). In addition, the root was washed within $1 \% \mathrm{O}_{\mathrm{s}} \mathrm{O}_{4}$ (osmium tetroxide) three times at $10 \mathrm{~min}$ intervals between each wash for post-fixed studies. Fixed root were dehydrated with acetone in different concentrations $(30,50,60,70,80,90,95$, and 100\%) AralditeDDSA (Ladd Research Industries, Williston). TEM Section observation was performed under TEM (FEI Tecnai TM G2 Spirit Twin, Hillsboro, USA) with an $80 \mathrm{KV}$ voltage velocity.

\subsection{Statistical analysis}

All the experiments were performed in triplicates. Further, to confirm the validity of data, an analysis of variance (ANOVA) was performed and significant differences in different parameters were verified by Duncan's multiple range tests (DMRT, $\mathrm{p} \leq 0.05$ ).

\section{Result and Discussion}

\subsection{Physico-chemical characteristics}

The Physico-chemical analysis of sludge sample showed the presence of high $\mathrm{pH}(8.2)$ and different ions i.e. $\mathrm{Na}^{+}, \mathrm{Cl}^{-}$and $\mathrm{K}^{+}$ concentration as beyond the permissible limit (Table 1). The sludge had higher values of TS (2678), TDS (2756), TSS (189), COD (43587), BOD (1569 $\left.\mathrm{mg} \mathrm{L}^{-1}\right)$ and EC (2067 $\mathrm{ms} \mathrm{cm}^{-1}$ ) value. Higher TDS and EC may be due to the presence of dissolved lignocellulosic particle, pith particle along with fine fibers and adequate concentration of salt and ions $\left(\mathrm{Na}^{+}, \mathrm{K}^{+}\right)$contents which contribute the salinity of effluent. This confirmed that the secondary treatment process in industry is not adequate to degrade the all complex pollutants present in effluents, The higher values of COD and organic content were due to release of various wood extract along with chemicals used in pulping process, which makes complex compounds. Moreover, the concentration of total phenol and lignin was also higher in sludge might be planted constituents and a major source of water pollution and cause serious problem for flora and fauna. The higher concentration of phenol is responsible for inhibiting the photosynthesis of algae, diatoms and another microorganism in the aquatic ecosystem. The black color of sludge appeared due to the presence of lignin and another organic compound during pulping and bleaching process. Moreover, the concentration of sulfate, nitrogen, and phosphate in sludge might be sodium sulfite, which is used during the pulping process and the nitrates detected in sludge possibly come from lignin (Singhal \& Thakur, 2009). Similarly, ions were also found in effluent which is generally more toxic than sulfates to flora and fauna including microbial community. Furthermore, the significant amounts of $\mathrm{Cu}\left(59.1 \mathrm{mg} \mathrm{L}^{-1}\right), \mathrm{Ni}\left(66.3 \mathrm{mg} \mathrm{L}^{-1}\right), \mathrm{Fe}\left(153.67 \mathrm{mg} \mathrm{L}^{-1}\right), \mathrm{Mn}(9.37$ 
Table 1 Physico-chemical characteristics of discharged sludge waste from different pulp paper industry. All the values are means of triplicate $(\mathrm{n}=3) \pm \mathrm{SD}$. Unit of all parameters is in $\mathrm{mg} \mathrm{L}^{-1}$ except $\mathrm{pH}$, color (Co-Pt. Unit) and $\mathrm{EC}\left(\mu \mathrm{mhoscm}^{-1}\right)$

\begin{tabular}{|c|c|c|}
\hline Parameters & Sludge value (mean) & Permissible limit (EPA 2002) \\
\hline $\mathrm{pH}$ & $8.6 \pm 0.25$ & $5-9$ \\
\hline Total solid & $2678 \pm 147$ & 2100.00 \\
\hline Total dissolved solid & $2756 \pm 0.05$ & - \\
\hline Total suspended solid & $189 \pm 0.13$ & 35 \\
\hline Chemical oxygen demand & $43587 \pm 230$ & 250 \\
\hline Biological oxygen demand & $1569 \pm 191$ & 30 \\
\hline Electrical conductivity & $2067 \pm 88$ & 1000 \\
\hline Total Phenols & $1027 \pm 19.34$ & 0.50 \\
\hline Total nitrogen & $654 \pm 0.21$ & 143 \\
\hline Sulphate & $3358 \pm 1456$ & 250 \\
\hline Phosphorus & $457 \pm 7.28$ & 200 \\
\hline $\mathrm{Cl}^{-}$ & $8.54 \pm 0.21$ & 1500 \\
\hline $\mathrm{Na}^{+}$ & $745 \pm 10.31$ & 200 \\
\hline $\mathrm{K}^{+}$ & $35.65 \pm 0.81$ & - \\
\hline Lignin & $49678 \pm 141.33$ & - \\
\hline Chlorophenol & $561 \pm 14.61$ & 3.0 \\
\hline \multicolumn{3}{|l|}{ Heavy metals (mg L-1 $)$} \\
\hline $\mathrm{Cu}$ & $59.1 . \pm 0.23$ & 2.00 \\
\hline $\mathrm{Ni}$ & $66.3 \pm 0.11$ & 0.50 \\
\hline $\mathrm{Fe}$ & $153.67 \pm 0.05$ & 0.01 \\
\hline $\mathrm{Mn}$ & $9.37 \pm 0.25$ & 0.10 \\
\hline $\mathrm{Zn}$ & $12.31 \pm 0.18$ & - \\
\hline $\mathrm{Mg}$ & $11.8 \pm 0.18$ & - \\
\hline
\end{tabular}

$\left.\mathrm{mg} \mathrm{L}^{-1}\right), \mathrm{Zn}\left(12.31 \mathrm{mg} \mathrm{L}^{-1}\right)$, and $\mathrm{Mg}\left(11.8 \mathrm{mg} \mathrm{L}^{-1}\right)$ were present in sludge which are hazardous to the environment. The heavy metals might be in sludge due to bioaccumulation by plants which are used as raw material for the making of the pulp as well as from various chemicals used during the pulping process in the industry.

\subsection{Scanning Electron Microscopy and UV-Vis Spectroscopy Analysis}

The SEM analysis of the sludge samples revealed the presence of the lignocellulosic organic polymer and organometallic compounds along with metals that are shown in Figure 1a. The results showed that the sludge image is irregular, elongated rod or cylindrical shaped bodies of different organic polymer present in the waste. Moreover, the release of different lignin and fibers component in sludge during the bleaching process was observed. Rod shaped structure might be cellulose, lignin or metals in sludge. The similar observation for the granulated appearance of lignin with the complete structure of different size has been reported in an earlier study (Liu et al., 2013). Furthermore, the irregular or oval shape is also indicating the lignin complexation with different heavy metals and another carbonyl, hydroxyl and phenolic compounds (Demirbas, 2007). In addition, the UV-Vis Spectral wavelength range of 250-700 analysis of sludge sample to assess the availability of dissolved organometallic compound present in sludge is the used method (Martins \& Boekel, 2003). The result indicated the height of different peak absorption in UV-region and their maximum absorbance was noted $\lambda_{\max } 320$ in the sludge as 
shown in Figure 1b. Further, the change of peak area and height was different indicating the difference of compound conversation into complex metabolites in nature from the contaminated site of the pulp paper industry (Chandra et al., 2011).

\subsection{Identification of persistent organic pollutants from sludge}

The identification of pollutants present in sludge extracted with DCM in details at different retention time (RT) based on mass spectra $(\mathrm{m} / \mathrm{z})$ in chromatogram was performed. The results revealed that sludge waste contained a large number of residual organic pollutants in range of (6.88 to 49.48$)$ characterized by GC-
MS (Table 2 and Figure 2). The detected major compounds as saturated fatty acids and EDCs compounds were observed. Additionally, six major peak compounds identified from sludge waste included 2 ethyl 4-6 dimethyl-1,3,5-trioxane (RT- 6.61), 1monopalmitin-ditms (RT-7.07), cinnamic acid- $\alpha$-phenyltrimethylsilyl ester (RT-8.28), heptane, 2, 2, 3, 3, 5, 6, 6heptamethyl (RT- 9.95), tetradecanoic methyl ester (RT-11.88) and hexadecanoic acid (RT- 32.08), respectively. The phenolic compounds present in sludge might introduce the dangerous effect of microbial and plant life in the soil and water. The cinnamic acids are the by-product of lignin and hemicellulose is generated dunging alkali bleaching process and this also produce ether linkages
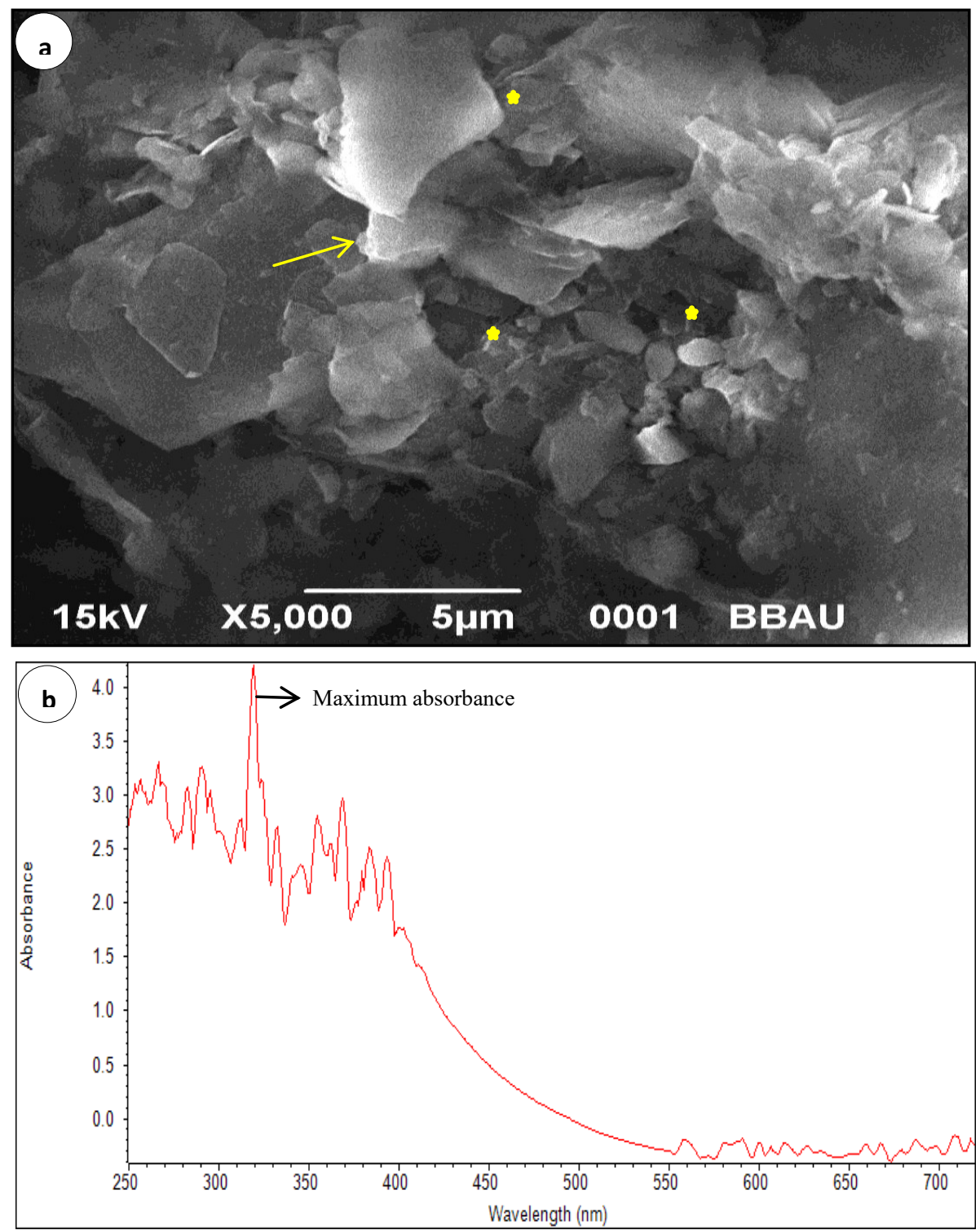

Figure 1 The SEM image pulp paper industry sludge (a) image showed the content of heavy metals and lignin (b) UV-Vis (250-700 nm) spectroscopy scanning analysis of different pollutants parameter.

Journal of Experimental Biology and Agricultural Sciences http://www.jebas.org 
Table 2 Identified residual organic pollutants by GC-MS in the TMS derivatized dichloromethane (DCM) extracts of pulp paper sludge waste after secondary treatment

RT Compound name $\quad \%$ similarity with NIST Library $\quad$ Toxicity

\begin{tabular}{|llll|}
\hline 6.61 & 2 ethyl 4-6 dimethyl-1,3,5-trixane & 61.87 & Data not reported \\
\hline 7.07 & 1- Monopalmitin-DITMS & 93.11 & Data not reported \\
\hline 8.28 & Cinnamic acid- $\alpha$-phenyl-trimethylsilyl ester & 82.02 & Data not available \\
\hline 9.95 & Heptane,2,2,3,3,5,6,6-heptamethyl & 85.29 & Data not available \\
\hline 11.88 & Tetradecanoic methyl ester & 66.94 & $\begin{array}{l}\text { Endocrine disrupting chemicals (EDC), } \\
\text { Comedogenic }\end{array}$ \\
\hline 12.85 & $\beta$ - Sitosterol & 57.11 & $\begin{array}{l}\text { EDC, genotoxic } \\
\text { and cytotoxic }\end{array}$ \\
\hline 23.23 & Decanol,2-hexyl & 84.57 & Data not available \\
\hline 27.46 & 1-Tetradecene & 73.69 & $\begin{array}{l}\text { Nervous system affected, EDC, and odor } \\
\text { nuisance }\end{array}$ \\
\hline 32.08 & Hexadecanoic acid & 68.17 & EDC, carcinogen \\
\hline 33.51 & $\begin{array}{l}\text { Bicycle(2.2.1)heptan-2-one,4-hydroxy-1,7,7- } \\
\text { trimethyl }\end{array}$ & 74.03 & Data not available \\
\hline 37.24 & Benzene dicarboxylic acid & & Data not available \\
\hline 43.93 & Eicosane (CAS) & 34.54 & EDCs \\
\hline 48.67 & Pentadecanoic acid, ethyl ester & 84.34 & EDCs \\
\hline
\end{tabular}

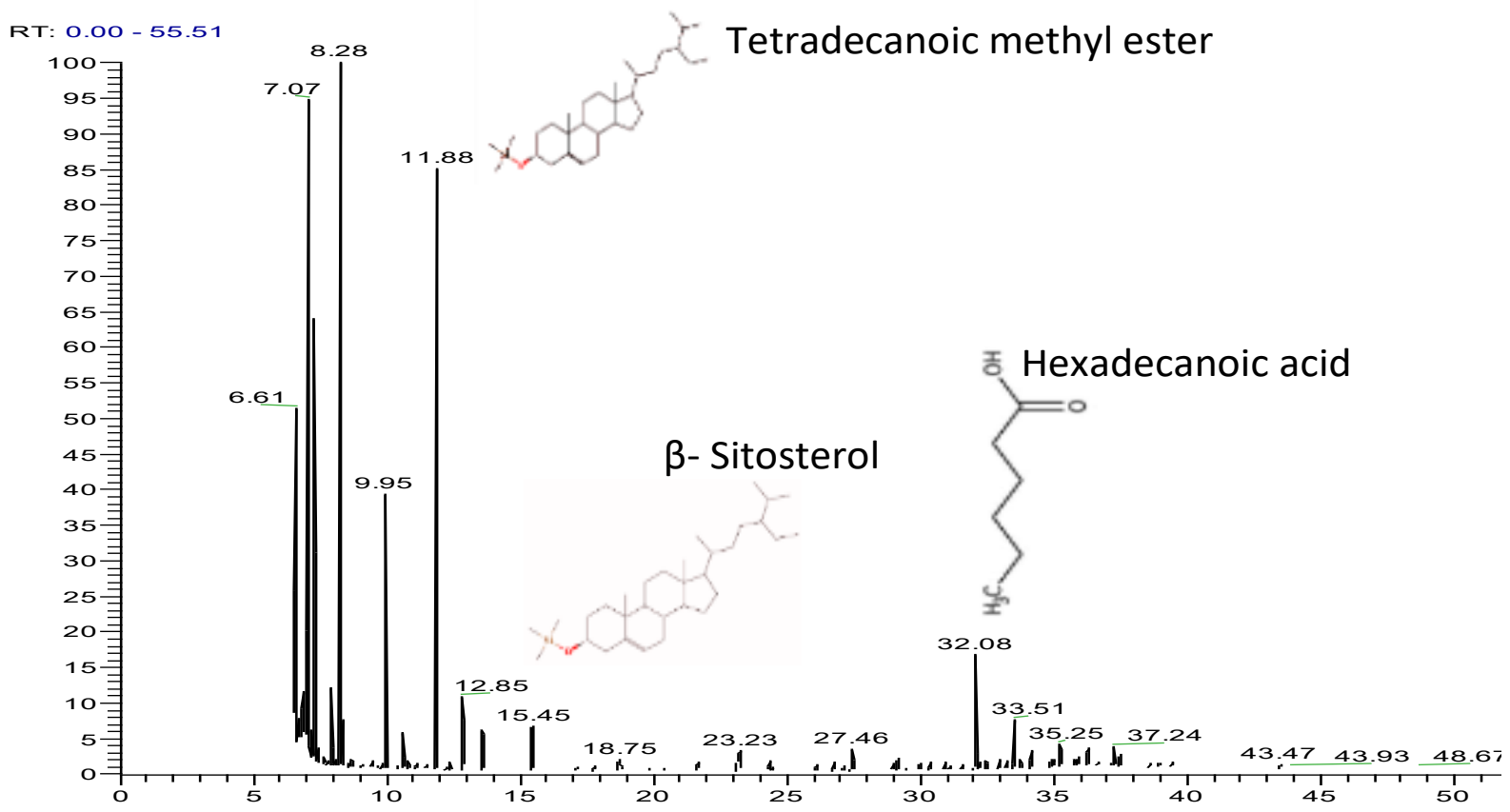

Figure 2 GC-MS chromatogram of residual organic pollutants extracted from sludge with dichloromethane.

and ester by the reaction of their carboxyl and phenolic groups (Jeffries, 1990). The hexadecanoic acid and pentadecanoic acid were characterized in current studies by analyzing plant fatty acids and antiquorum sensing molecules of the bacterial product. These complex pollutants in sludge are generated during the pulping and bleaching process in industrial. Similar compounds have been reported by various researchers (ATSDR, 2007). Moreover, several studies have confirmed that these compounds have also been reported in sludge and cause serious health problem with mutagenic and carcinogenic nature (Yadav \& Chandra, 2018). In addition, some other hazardous organic compounds were present in sludge waste such as $\beta$ - sitosterol (RT-12.85), decanol, 2-hexyl 
(RT-23.23) and benzene dicarboxylic acid (RT-37.24). Also, some phenolic and non-phenolic compounds extracted i.e. benzene dicarboxylic acid have also been obtained in sludge waste and are responsible for casing skin disease. In an earlier study, it has been reported that aerobic and anaerobic microbes are able to transform $\beta$-sitosterol and other sterols into androgenic hormones, i.e. $5-\beta$ androstane 3, 17-dione and androstane 4-en-3, 17-dione (Chandra et al., 2018). Furthermore, some studies reported toxicity compounds in aquatic ecosystems and DNA damage inducer in a human melanoma cell line, respectively (Kamaya et al., 2003; de Sousa Andrade et al., 2005). Moreover, these compounds are also listed under EDCs as per USEPA (2012) guideline. In addition, the huge amount of existing carbon was due to the cellulose throughout the sludge from the production process and its procedures (Sutcu \& Akkurt, 2009). Consequently, these compounds have been considered as key constituents of environmental pollutants responsible for dermal irritation and eye. The result indicated that persistent organic pollutants present in sludge and their toxicity were very high for crop plants.

\subsection{Effect of heavy metals on biochemical parameters}

\subsubsection{Effect on protein content and photosynthetic pigments}

The estimation of protein content in B. campestris and C. album plants growing at the sludge was found higher in comparison to control. Moreover, the study investigates that the protein content affecting plants also gets enhanced significantly $(\mathrm{p} \leq 0.05)$, respectively. The protein content recorded for sludge affected $C$. album plants was 5.173 and $5.367 \mathrm{ug} / \mathrm{ml}$, whereas for $B$. campestris plants it was 4.697 and $5.349 \mathrm{ug} / \mathrm{ml}$, respectively. The excess supply of micro and macronutrients encourages the accumulation of amino acids and improves the protein content as well as provides high proline formation that provides stress tolerance capacity through multiple processes such as osmoregulation and enzyme protection against distinct stress circumstances. Furthermore, the high content of proteins in $B$. campestris and $C$. album revealed the induction of many stress proteins growing at chlorolignins contain sludge. Our study revealed higher content of chlorophyll a, b and carotenoids as recorded in B. campestris and C. album leaves growing at the disposal site of sludge bed in comparisons to control. The increased concentrations of Chl-a and Chl-b in B. campestris and C. album plants can be connected with the existence of macro and micronutrients, i.e. $\mathrm{Cu}$ - Plastocynin, protein, $\mathrm{Fe}$ contains electron transports in cytochrome chains as well as multiple organic and inorganic contaminants (Sheetal et al., 2016). The ratio among chl $\mathrm{a}$ and $\mathrm{chl} \mathrm{b}$ is also a significant parameter and its increase has been correlated with lower rates of light chlorophyll protein harvesting (LHCP) (Mobin \& Khan, 2007). Chlorophyll response is among the most important responses to stress in plants. In addition, the concentration of carotenoids was expected to work as antioxidants by scavenging free radicals, transferring electrons to dual bond structure and eliminating light damage, cell damage, destruction of chloroplast membranes and genetic material by photodynamic response, quenching, membrane collapse and replacement of peroxidation by enhanced accumulation of hazardous metals and metalloids (Czerpak et al., 2006). Several researchers documented harmful effects of heavy metals on light and dark reactions as well as on decreased photosynthetic pigments, stomatal conductivity and transpiration rate (Appenroth, 2010). Leaf chlorosis due to loss of chlorophyll and carotenoids and plant stunting and root browning are common indications of metal toxicity in plants (Bahmani et al., 2012). Effects include reduced degradation of chlorophyll, altered water balance, decreased production of various enzymes, stomata closure, slowing down of photosynthesis and decreased absorption of important minerals nutrients (Nagajyoti et al., 2010).

\subsection{Effects on antioxidants enzyme}

\subsubsection{Catalase, peroxidase and ascorbate assay}

Comparative pollutants and their toxicity analysis of sludge waste are affecting B. campestris and C. album plants as showed more CAT activity as primary biomarkers for the removal of $\mathrm{H}_{2} \mathrm{O}_{2}$ produced during the metal stress in form of the peroxisomes (Karuppanapandian et al., 2011). Furthermore, the catalase activity decreased due to the low concentration of hazardous pollutants from sludge. In addition, the concentration of POD and ascorbate is increased in B. campestris and C. album at disposal site of sludge as comparing to control. The high POD levels enhanced the elimination of $\mathrm{H}_{2} \mathrm{O}_{2}$ and thus diminished the formation of hydroxyl radicals and preventing the damage of chlorophylls.

\subsubsection{Superoxide dismutase and ascorbate peroxidase assay}

The collected plants such as B. campestris and C. album grow on sludge waste affected show maximum SOD (214.21 and 112.29 Unit $\mathrm{gm}^{-1} \mathrm{fw}$ ) in a comparison to control (growing on agriculture land), respectively. Moreover, the sludge waste B. campestris and C. album plants revealed a significant reduction in SOD activity (106.23 and 98.20 Unit $\mathrm{gm}^{-1} \mathrm{fw}$ ), respectively $(\mathrm{p} \leq 0.05)$ under potentially harmful toxic element stress in sludge in comparison to control plants. The content of SOD is mostly present in algae and plants with a competent biochemical and scavenging machinery i.e. enzymatic and non-enzymatic antioxidants including SOD, APX, CAT, and Glutathione to control reactive oxygen species (ROS) levels to check the toxicity under the wide environmental stress. Moreover, SOD will catalyze the decomposition of superoxide and detoxification mechanism such as anion into radical oxygen, hydrogen peroxide and then converted to the ground level of $\mathrm{O}_{2}$ and $\mathrm{H}_{2} \mathrm{O}$ and usually depends on the potentially 
toxic metals cofactors. In addition, the activity of APX enhance was observed in the sludge waste affected $C$. album plants as well as $B$. campestris plants under potential toxic metal stress in comparison to control plants, while the sludge waste affected $B$. campestris and C. album plants showed the less amount of metal toxicity, therefore, no significant change in control and waste affected plants was observed. Consequently, APX is the plant's cell shown as an amino acid sequence (Asada, 1992).

\subsection{Accumulation of metals in B. campestris and C. album}

The analysis of different of heavy metals concentration in sludge affected growth and accumulation of metals in their root, shoots and leaves parts of B. campestris and C. album (Table 3 and Figure 3). The collected sludge sample was found to have a high concentration of different heavy metals i.e. $\mathrm{Cu}, \mathrm{Ni}, \mathrm{Fe}, \mathrm{Mn}, \mathrm{Zn}$ and $\mathrm{Mg}$ that were above the permissible limit. Among these two, $C$. album had low bioaccumulation factor (BAF) values regarding soil $\mathrm{Cd}$ concentrations reported by Parisien et al. (2015). Similarly, Gupta \& Sinha, (2008) reported that C. album had a remarkable accumulation of $\mathrm{Fe}, \mathrm{Mn}, \mathrm{Cd}, \mathrm{Cr}, \mathrm{Cu}, \mathrm{Ni}, \mathrm{Pb}$ and $\mathrm{Zn}$. Moreover, the accumulation and distribution of metals in the plant are depending on metal bioavailability and plant metabolism, as well as on the growth of microbes in contaminated sites responsible for uptake of metals in a plant (Mani \& Rayappan, 2014; Balkhair \& Ashraf, 2016). The increase in concentration of heavy metals in different parts of plant was observed as compared to control. Among these metals, the maximum and minimum amounts of $\mathrm{Fe}$ and $\mathrm{Ni}$ in $B$. campestris and C. album were recorded, respectively, which may be due to higher absorbing capacity of these elements. The mechanism of metal absorption in various parts of the plant is significantly influenced by wastewater contents such as $\mathrm{pH}$, cation exchange capability, organic matter and metal concentration. The highest accumulation of $\mathrm{Fe}$ were noted in $B$. campestris root $(261.02 \mathrm{mg} \mathrm{kg})>$ shoot $\left(188.01 \mathrm{mg} \mathrm{kg}^{-1}\right)>$ leaves
(211.00 mg kg ${ }^{-1}$ ), while the highest concentration of Fe were noted in C. album root $\left(217.00 \mathrm{mg} \mathrm{kg}^{-1}\right)>$ shoot $\left(186.00 \mathrm{mg} \mathrm{kg}^{-1}\right)>$ leaves (208.00 $\mathrm{mg} \mathrm{kg}^{-1}$ ), respectively. Soil $\mathrm{pH}$ is an essential factor in regulating the availability of metals to plants. The bioavailability of $\mathrm{Cu}$ and $\mathrm{Zn}$ is mainly regulated by $\mathrm{pH}$ and organic carbon content, while low solubility of Mn was observed at neutral to alkaline pH levels (Bose \& Bhattacharyya, 2008). Plants showed the maximum accumulation of $\mathrm{Fe}$ followed by $\mathrm{Cu}$ and $\mathrm{Zn}$ in root and shoot of B. campestris and $C$. album plants. The accumulation and distribution pattern of different metals in different parts of $B$. campestris and $C$. album plants growing on the sludge was recorded as leaves $>$ shoot $>$ root for $\mathrm{Cu}$, shoot $>$ root $>$ leaves for $\mathrm{Zn}$, root>shoot>leaves for $\mathrm{Mn}$, shoot $>$ root $>$ leave for $\mathrm{Mg}$, roots $>$ shoot $>$ leaves for $\mathrm{Ni}$, B. campestris and C. album plants and shoot $>$ leaves $>>$ root for $\mathrm{Cu}$, shoot $>$ leaves $>$ root for $\mathrm{Zn}$, leave $>$ shoot $>$ root for $\mathrm{Mn}$, leaves $>$ shoot $>$ roots for $\mathrm{Mg}$, leaves $>$ shoot $>$ roots for $\mathrm{Ni}$, in $C$. album plants. Concentrations of all metals varied widely different parts of $B$. campestris and $C$. album plants. Heavy metals caused oxidative stress, including directly, including $\mathrm{Cu}$, by Haber-Weiss and Fenton reactions, or indirectly, by inducing imbalances in the antioxidant system (Keunen et al., 2011).

\subsection{Cellular observations metals in root tissues}

The TEM analysis of B. campestris and C. album in root tissue showed seemingly metals deposition near the mitochondria, chloroplast, cell wall, intercellular spaces and thinning of the cell wall as showed in Figure 4. Many researches on Brassica species confirm reduced root growth under different heavy metals (John et al., 2009). The toxic effect of heavy metals on B. campestris and C. album plant cellular organization is an important factor in understanding the physiological and morphological alterations induced by heavy metals due to the complementarity of structure and function (Bini et al., 2012). In addition, root tissue of $B$.

Table 3 Heavy metal accumulations ( $\left.\mathrm{mg} \mathrm{kg}^{-1} \mathrm{DW}\right)$ in the root, shoot, and leave of B. campestris and C. album plant species growing on sludge. All the values are mean of three replicates $(n=3) \pm$ standard deviation (SD), R: Root, S: Shoot, L: Leaves

\begin{tabular}{|c|c|c|c|c|c|c|c|}
\hline \multirow{2}{*}{ Plants name } & \multirow{2}{*}{ Plants parts } & \multicolumn{6}{|c|}{ Heavy metals ( $\mathrm{mg} \mathrm{kg}^{-1}$ ) } \\
\hline & & $\mathrm{Cu}$ & $\mathrm{Ni}$ & $\mathrm{Fe}$ & Mn & $\mathrm{Zn}$ & $\mathrm{Mg}$ \\
\hline \multirow[t]{3}{*}{ B. campestris } & Root & $45.56 \pm 1.20$ & $9.36 \pm 0.30$ & $261.02 \pm 0.05$ & $43.64 \pm 0.50$ & $49.44 \pm 0.05$ & $41.33 \pm 0.10$ \\
\hline & Shoot & $58.36 \pm 0.50$ & $6.37 \pm 0.20$ & $188.01 \pm 0.05$ & $39.67 \pm 0.54$ & $52.21 \pm 0.04$ & $56.74 \pm 0.20$ \\
\hline & Leaves & $62.37 \pm 1.27$ & $4.22 \pm 0.20$ & $211.00 \pm 0.05$ & $36.37 \pm 0.67$ & $34.26 \pm 1.16$ & $35.69 \pm 0.25$ \\
\hline Accumulation pattern & & $L>S>R$ & $R>S>L$ & $R>L>S$ & $R>S>L$ & $S>R>L$ & $S>R>L$ \\
\hline \multirow[t]{3}{*}{ C. album } & Root & $42.36 \pm 1.23$ & $4.37 \pm 0.10$ & $217.00 \pm 0.05$ & $30.23 \pm 0.20$ & $39.49 \pm 0.05$ & $9.49 \pm 0.10$ \\
\hline & Shoot & $54.74 \pm 1.94$ & $5.41 \pm 0.13$ & $186.00 \pm 0.05$ & $36.54 \pm 0.24$ & $43.04 \pm 0.05$ & $11.79 \pm 0.20$ \\
\hline & Leaves & $49.87 \pm 1.21$ & $6.51 \pm 0.18$ & $208.00 \pm 0.05$ & $42.37 \pm 0.60$ & $56.67 \pm 1.10$ & $13.64 \pm 0.20$ \\
\hline Accumulation pattern & & $S>L>R$ & $L>S>R$ & $R>L>S$ & $L>S>R$ & $L>S>R$ & $L>S>R$ \\
\hline
\end{tabular}

Journal of Experimental Biology and Agricultural Sciences http://www.jebas.org 


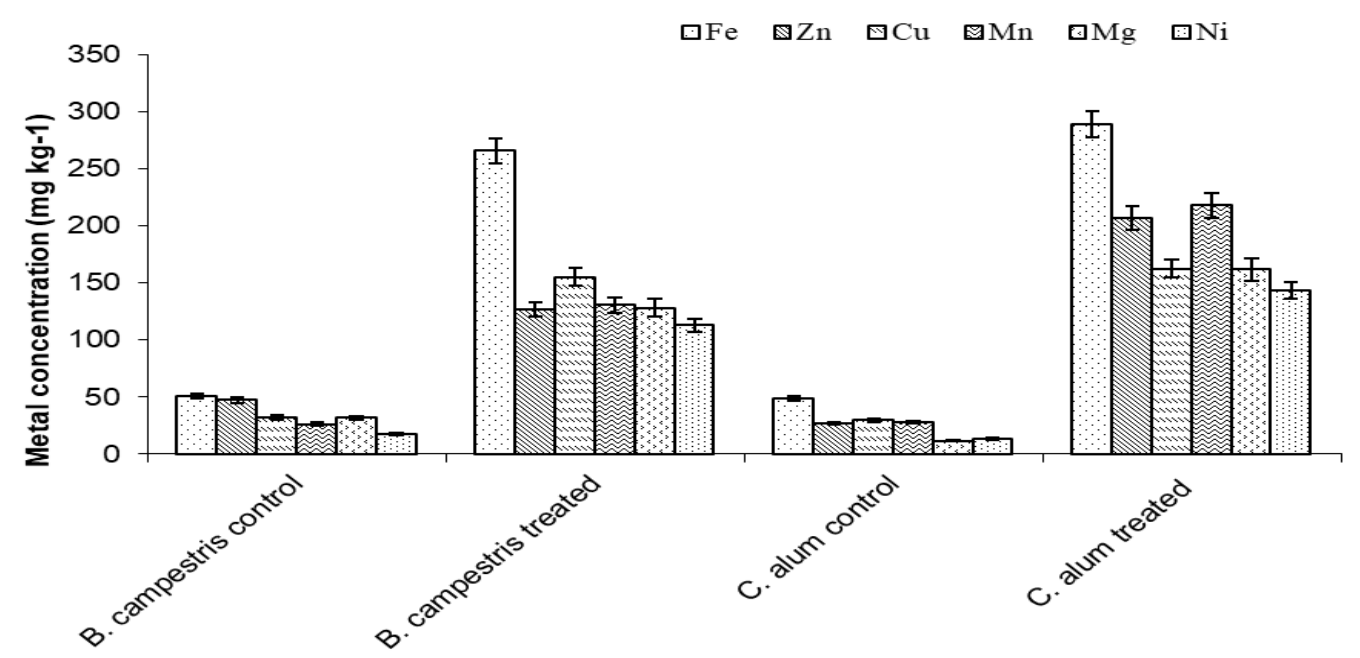

a
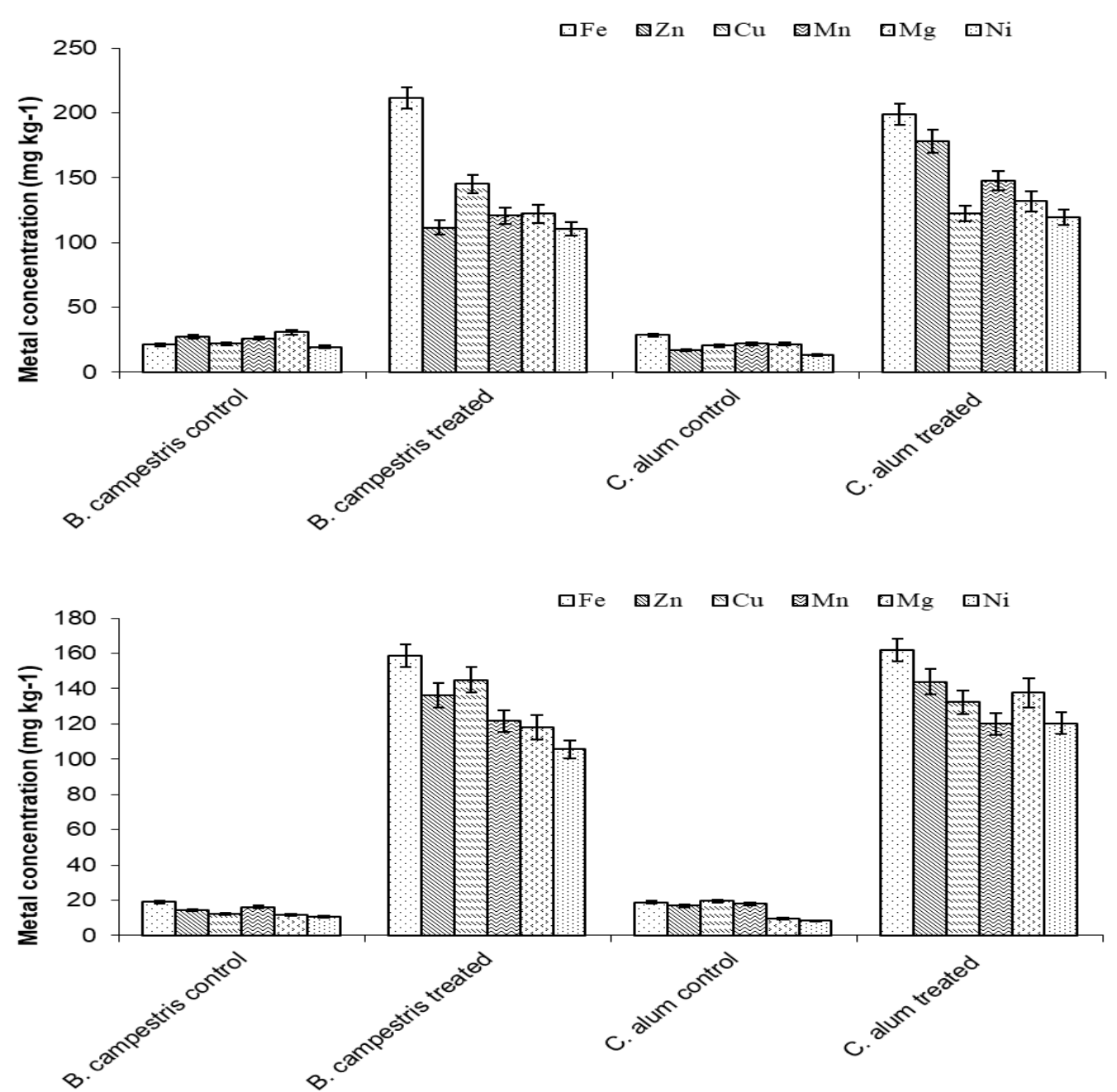

Figure 3 Accumulation of $\mathrm{Fe}, \mathrm{Zn}, \mathrm{Cu}, \mathrm{Mn}, \mathrm{Mg}$ and $\mathrm{Ni}$ in root (a), shoot (b) and leaves

(c) of B. campestris and C. alum collected from pulp paper sludge waste site

Journal of Experimental Biology and Agricultural Sciences http://www.jebas.org 

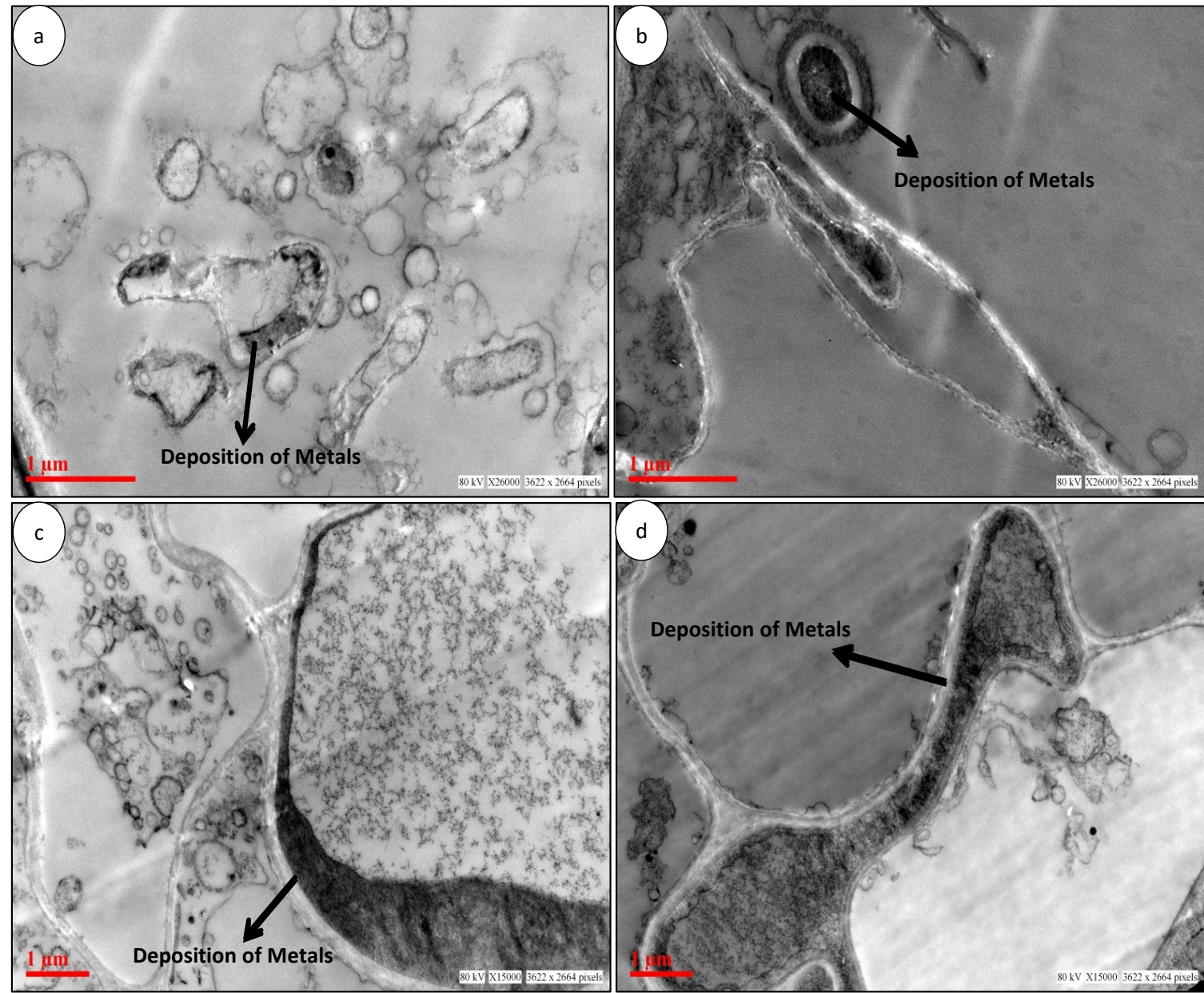

Figure 4 TEM analyses of $B$. campestris and $C$. alum plant root after accumulation of heavy metals from treated sludge waste.

campestris showed a reduction of intercellular spaces, plastids and abnormal cell shape (Figure 4a-b). The above observation proved that B. campestris and C. album will have more metal tolerance capacity. Similar observations were also reported by Sridhar et al. (2005) in B. juncea leaf. Seed germination may also be affected by heavy metals in Brassica (Siddiqui et al., 2014). The change in shape of chloroplast due abiotic and biotic stresses is the result of an increased volume of the stroma and disorganization of the thylakoid membranes which have been previously reported in the literature (Vijaranakul, 2001). Moreover, the root tissue of $C$. album showed deposition of electron-dense granules of metals in cell cytoplasm is the ability of phytoaccumulation by the plant.

\section{Conclusion}

The results of this study conclude that environmental pollutants discharged from the pulp paper industry sludge are directly or indirectly linked with human and animal health through the food chain. The current study revealed that physico-chemical analysis of sludge waste consists of potentially toxic elements along with organic compounds which are above the acceptable limit. In addition, this can also be concluded that sludge waste $B$. campestris and C. album plants have high metal accumulation and allocation in their aerial parts. Furthermore, the antioxidant enzyme analysis of B. campestris and $C$. album revealed increased antioxidants activity. Therefore, there is a need of continuous monitoring near the pulp paper industrial area of the soil and groundwater conditions for eco-restoration and environmental safety. Moreover, human health's threats are extensive researched on a worldwide scale, but only a few studies have used adequate observational strategies.

\section{Acknowledgment}

This work is supported by Department of Biotechnology (DBT), New Delhi, India vide letter no. BT/PR18896/BCE/8/1372/2016 Dated 28.3.2018. The instrumentation facilities for Scanning Electron Microscopy (SEM) from USIC, BBAU Lucknow, Uttar 
Pradesh, while the Transmission Electron Microscopy (TEM) analysis from CSIR-Indian Institute of Toxicology Research (IITR), Lucknow, Utter Pradesh, are gratefully acknowledged.

\section{Conflict of Interest}

The authors declare that they have no conflict of interest

\section{Reference}

Ali M, Sreekrishnan TR (2001) Aquatic toxicity from pulp and paper mill effluents: a review. Advances in Environmental Research 5: 175-196. https://doi.org/10.1007/s11368-020-02610-6.

American Public Health Association (2012) Standard Method for Examination of Water and Wastewater, 22nd ed. Washington, DC.

AOAC (2002) Official Method of Analysis of AOAC International. In: William H. (Ed.), 17th edn. AOAC International.

Appenroth KJ (2010) Definition of "heavy metals" and their role in biological systems. In Soil heavy metals (19-29). Springer, Berlin, Heidelberg. https://doi.org/10.1007/978-3-642-02436-82.

Arnon DI (1949) Copper enzymes in isolated chloroplasts Polyphenol oxidase in Beta vulgaris. Plant Physiology 24: 1-16. https://doi.org/10.1104/pp.24.1.1.

Asada K (1992) Ascorbate peroxidase-a hydrogen peroxide-scavenging enzyme in plants. Physiologia Plantarum 85 235-241. https://doi.org/10.1111/j.1399-3054.1992.tb04728.x.

ATSDR (2007) Toxicological Profile for Barium. U.S. Department of Health and Human Services, Public Health Service, Atlanta, GA.

Bahmani R, Bihamta MR, Habibi D, Forozesh P, Ahmadvand S (2012) Effect of cadmium chloride on growth parameters of different bean genotypes (Phaseolus vulgaris L.). ARPN Journal Agriculture Biology Science 7: 35-40. https://doi.org/10.13140/RG.2.1.2159.6329.

Bajpai P (2015) Generation of waste in pulp and paper mills. In: Management of Pulp and Paper Mill Waste (9-17) Springer, Cham. https://doi.org/10.1007/978-3-319-11788-12.

Balkhair KS, Ashraf MA (2016) Field accumulation risks of heavy metals in soil and vegetable crop irrigated with sewage water in western region of Saudi Arabia. Saudi Journal of Biological Sciences 23: S32-S44. https://doi.org/10.1016/j.sjbs.2015.09.023.

Bayık Demirel G, Altın A (2017) Production of sorbent from paper industry solid waste for oil spill cleanup. Marine pollution bulletin 125: 341-349. https://doi.org/10.1016/j.marpolbul.2017.09.040.
Bini C, Wahsha M, Fontana S, Maleci L (2012) Effects of heavy metals on morphological characteristics of Taraxacum officinale Web growing on mine soils in NE Italy. Journal of Geochemical Exploration 123: 101108. http://doi.org/10.1016/j.geoexplo.2012.07.009.

Boni MR, Aprile DL, De Casa G (2004) Environmental quality of primary paper sludge. Journal of Hazardous Materials 108: 125128. http://doi.org/10.1016/j.jhazmat.2003.11.017.

Bose S, Bhattacharyya AK (2008) Heavy metal accumulation in wheat plant grown in soil amended with industrial sludge. Chemosphere 70: 1264-1272. http://doi.org/10.1016/j.chemosphere.2007.07.062.

Chandra R, Abhishek A (2011) Bacterial decolorization of black liquor in axenic and mixed condition and characterization of metabolites. Biodegradation 22: 603-611.

http://doi.org/10.1007/s10532-010-9433-1.

Chandra R, Abhishek A, Sankhwar M (2011) Bacterial decolorization and detoxification of black liquor from rayon grade pulp manufacturing paper industry and detection of their metabolic products. Bioresource $\quad$ Technology 102: 6429-6436. https://doi.org/10.1016/j.biortech.2011.03.048.

Chandra R, Kumar V, Tripathi S (2018) Evaluation of molassesmelanoidin decolourisation by potential bacterial consortium discharged in distillery effluent. 3 Biotech 8: 187. https ://doi.org/10.1007/s1320 5-018-1205-3.

Chandra R, Singh R (2012) Decolorization and detoxification of rayon grade pulp paper mill effluent by mixed bacterial culture isolated from pulp paper mill effluent polluted site. Biochemical Engineering Journal 61: 49-58.

https ://doi.org/10.1016/j.bej.2011.12.004.

Czerpak R, Piotrowska A, Szulecka K (2006) Jasmonic acid affects changes in the growth and some components content in alga Chlorella vulgaris. Acta Physiologiae Plantarum 28: 195-203. https://doi.org/10.1007/BF02706531.

de Sousa Andrade LN, De Lima TM, Curi R, de Lauro Castrucci AM (2005) Toxicity of fatty acids on murine and human melanoma cell lines. Toxicology in Vitro 19: 553-560. https://doi.org/10.1016/j.tiv.2005.02.002.

Demirbas A (2007) Adsorption of Co (II) and Hg (II) from water and wastewater onto modified lignin. Energy Sources, Part A 29(2): 117-123. https://doi.org/10.1016/j.tiv.2005.02.002.

Duxbury AC, Yentsch CS (1956) Plankton pigment nomographs. Technical report no 53 and 54. 
EPA (1996) Test Methods for Evaluating Solid Waste. SW-8460 Method 3050-B. U.S. Environmental Protection Agency, Office of Research and Development, Cincinnati.

EPA (2002) Environmental Protection Rules, 3A, Schedule-II, III. U.S. Environmental Protection Agency. Office of research and development, Cincinnati.

Gupta AK, Sinha S (2008) Decontamination and/or revegetation of fly ash dykes through naturally growing plants. Journal of Hazardous Materials, 153: 1078-1087. https://doi.org/10.1016/j.jhazmat.2007.09.062.

Integrated Pollution Prevention and Control (IPPC) (2001) Reference Document on Best Available Techniques in the Pulp and Paper Industry. European Commission, December.

Jeffries TW (1990) Biodegradation of lignin-carbohydrate complexes. Biodegradation 1: 163-176.

John R, Ahmad P, Gadgil K, Sharma S (2009) Cadmium and leadinduced changes in lipid peroxidation, antioxidative enzymes and metal accumulation in Brassica juncea L. at three different growth stages. Archives of Agronomy and Soil Science 55: 395-405. https://doi.org/10.1080/03650340802552395.

Kamaya Y, Kurogi Y, Suzuki K (2003) Acute toxicity of fatty acids to the freshwater green alga Selenastrum capricornutum. Environmental Toxicology 18(5): 289-294. https://doi.org/10.1002/tox.10127.

Karuppanapandian T, Moon JC, Kim C, Manoharan K, Kim W (2011) Reactive oxygen species in plants: their generation, signal transduction, and scavenging mechanisms. Australian Journal of Crop Science 5: 709-725.

Keller T, Schwager H (1977) Air pollution and ascorbic acid European Journal of Forest Pathology 7: 338-350.

Keunen E, Remans T, Bohler S, Vangronsveld J, Cuypers A (2011) Metal-induced oxidative stress and plant mitochondria. International Journal of Molecular Sciences 12: 6894-6918. https://doi.org/10.3390/ijms12106894.

Khan DH, Duckett JG, Frankland B, Kirkham JB (1984) An X-ray microanalytical study of the distribution of cadmium in roots of Zea mays L. Journal of Plant Physiology 115: 19-28. https://doi.org/10.1016/S0176-1617(84)80047-4.

Khan FUA, Rahman U, Jan A, Riaz M (2004) Toxic and trace metals $(\mathrm{Pb}, \mathrm{Cd}, \mathrm{Zn}, \mathrm{Cu}, \mathrm{Mn}, \mathrm{Ni}, \mathrm{Co}$ and $\mathrm{Cr}$ ) in dust, dust fall/soil. Journal of the Chemical Society of Pakistan 26: 453-456. https://doi.org/10.1155/2019/6730305.
Liu X, Zhu H, Qin C, Zhou J, Zhao JR, Wang S (2013) Adsorption of heavy metal ion from aqueous single metal solution by aminated epoxy-lignin. BioResources 8: 2257-2269. https://doi.org/10.15376/biores.8.2.2257-2269.

Lowry OH, Rosebrough NJ, Farr AL, Randall RJ (1951) Protein measurement with the Folin phenol reagent. Journal of Biological Chemistry 193: 265-275.

Mani GK, Rayappan JBB (2014) Novel and facile synthesis of randomly interconnected $\mathrm{ZnO}$ nanoplatelets using spray pyrolysis and their room temperature sensing characteristics. Sensors and Actuators B: Chemical 198: 125-133.

https://doi.org/10.1016/j.snb.2014.02.101.

Martins SI, Boekel MA (2003) Melanoidins extinction coefficient in the glucose/glycine Maillard reaction. Food Chemistry 83: 135142. https://doi.org/10.1016/S0308-8146(03)00219-X.

Mobin M, Khan NA (2007) Photosynthetic activity, pigment composition and antioxidative response of two mustard (Brassica juncea) cultivars differing in photosynthetic capacity subjected to cadmium stress. Journal of Plant Physiology 164: 601-610. https://doi.org/10.1016/j.jplph.2006.03.003.

Mourato MP, Moreira IN, Leitao I, Pinto FR, Sales JR, Martins LL (2015) Effect of heavy metals in plants of the genus Brassica. International Journal of Molecular Sciences 16: 1797517998. https://doi.org/10.3390/ijms160817975.

Nagajyoti PC, Lee KD, Sreekanth TVM (2010) Heavy metals, occurrence and toxicity for plants: a review. Environmental Chemistry Letters 8: 199-216. https://doi.org/10.1007/s10311-0100297-8.

Nakano Y, Asada K (1981) Hydrogen Peroxide is Scavenged by Ascorbate-specific Peroxidase in Spinach Chloroplasts. Plant and Cell Physiology 22: 867-880.

https://doi.org/10.1093/oxfordjournals.pcp.a076232.

Nishikimi M, Rao NA, Yagi K (1972) The occurrence of superoxide anion in the reaction of reduced phenazine methosulfate and molecular oxygen. Biochemical and Biophysical Research Communications 46: 849-854. https://doi.org/10.1016/S0006-291X(72)80218-3.

Onsa GH, Bin Saari N, Selamat J, Bakar J (2004) Purification and characterization of membrane-bound peroxidases from Metroxylon sagu. Food Chemistry, 85(3), 365-376.

https://doi.org/10.1016/j.foodchem.2003.07.013.

Parisien MA, Rutter A, Zeeb BA (2015) Feasibility of using phytoextraction to remediate a compost-based soil contaminated 
with cadmium. International Journal of Phytoremediation 17 1137-1143. https://doi.org/10.1080/15226514.2014.1003792.

Savant DV, Abdul-Rahman R, Ranade DR (2006) Anaerobic degradation of adsorbable organic halides (AOX) from pulp and paper industry wastewater. Bioresource Technology 97: 10921104. https://doi.org/10.1016/j.biortech.2004.12.013.

Seneviratne M, Rajakaruna N, Rizwan M, Madawala HMSP YS, Vithanage M (2019) Heavy metal-induced oxidative stress on seed germination and seedling development: a critical review. Environmental Geochemistry and Health 41: 1813-1831. https://doi.org/10.1007/s10653-017-0005-8.

Sheetal KR, Singh SD, Anand A, Prasad S (2016) Heavy metal accumulation and effects on growth, biomass and physiological processes in mustard. Indian Journal of Plant Physiology 21: 219 223. https://doi.org/10.1007/s40502-016-0221-8.

Siddiqui MM, Abbasi BH, Ahmad N, Ali M, Mahmood T (2014) Toxic effects of heavy metals $(\mathrm{Cd}, \mathrm{Cr}$ and $\mathrm{Pb})$ on seed germination and growth and DPPH-scavenging activity in Brassica rapa var. turnip. Toxicology and Industrial Health 30: 238-249. https://doi.org/10.1177/0748233712452605.

Singhal A, Thakur IS (2009) Decolourization and detoxification of pulp and paper mill effluent by Cryptococcus sp. Biochemical Engineering Journal 46: 21-27. https://doi.org/10.1016/j.bej.2009.04.007.

Sridhar BM, Diehl SV, Han FX, Monts DL, Su Y (2005) Anatomical changes due to uptake and accumulation of $\mathrm{Zn}$ and $\mathrm{Cd}$ in Indian mustard (Brassica juncea). Environmental and
Experimental Botany 54: 131-141.

https://doi.org/10.1016/j.envexpbot.2004.06.011.

Sutcu M, Akkurt S (2009) The use of recycled paper processing residues in making porous brick with reduced thermal conductivity. Ceramics International 35: 2625-2631. https://doi.org/10.1016/j.ceramint.2009.02.027.

Tozser D, Tothmeresz B, Harangi S, Baranyai E, Lakatos G, Fulop Z, Simon E (2019) Remediation potential of early successional pioneer species Chenopodium album and Tripleurospermum inodorum. Nature Conservation 36: 47. https://doi.org/10.3897/natureconservation.36.32503.

UN-HABITAT (2004) the State of the World's Cities: Globalization and Urban Culture. UN-HABITAT, Human Settlements Programme, Nairobi.

USEPA (2012) US environmental protection agency endocrine disruptor screening program universe of chemicals.

Velikova V, Yordanov I, Edreva A (2000) Oxidative stress and some antioxidant systems in acid rain-treated bean plants. Protective role of exogenous polyamines. Plant Sciences 151:59-66.

Vijaranakul U, Jayaswal RK, Nadakavukaren MJ (2001) Alteration in chloroplast ultrastructure of suspension cultured Nicotiana tabaccum cells by cadmium. Science Asia 27: 227-231.

Yadav S, Chandra R (2018) Detection and assessment of the phytotoxicity of residual organic pollutants in sediment contaminated with pulp and paper mill effluent. Environmental Monitoring and Assessment 190: 581-595. https://doi.org/10.1007/s10661-018-6947-1. 